\title{
Calcitization of Mg-Ca carbonate and Ca sulphate deposits in a continental Tertiary basin (Calatayud Basin, NE Spain)
}

\author{
E. Sanz-Rubio ${ }^{\mathrm{a}, *}$, S. Sánchez-Moral ${ }^{\mathrm{b}}$, J.C. Canaveras ${ }^{\mathrm{c}}$, J.P. Calvo ${ }^{\mathrm{d}}$, J.M. Rouchy ${ }^{\mathrm{e}}$ \\ ${ }^{a}$ Centro de Astrobiologla (INTA-CSIC), Carretera de Ajalvir km 4, 28850 Torrejón de Ardoz, Madrid, Spain \\ ${ }^{\mathrm{b}}$ Museo Nacional de Ciencias Naturales (CSIC), Departamento de Geología, Cl José Gutiérrez Abascal 2, 28006 Madrid, Spain \\ 'Departamento de Ciencias dela TierraydelMedio Ambiente, Facultad de Ciencias, Universidad de Alicante, 03080 San Vicente Raspeig, \\ Alicante, Spain \\ ${ }^{\mathrm{d} D e p a r t a m e n t o ~ d e ~ P e t r o l o g i a ~ y ~ G e o q u i m i c a, ~ F a c u l t a d ~ d e ~ C i e n c i a s ~ G e o l o ́ g i c a s, ~ U n i v e r s i d a d ~ C o m p l u t e n s e, ~} 28040$ Madrid, Spain

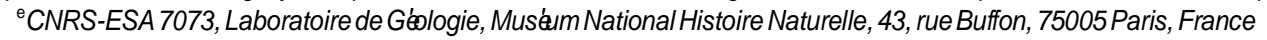

\begin{abstract}
Diagenetic carbonates formed through early calcitization of evaporite (gypsum, anhydrite) and/or magnesium carbonate (dolomite, magnesite) deposits have been identified throughout the Tertiary Calatayud Basin (NE Spain). The diagenetic carbonates consist in all cases of low magnesian calcite and are related to main sedimentary discontinuities, which record episodes of significant subaerial exposure in the basin. Early calcite replacements predominate in sediments of the Intermediate Unit in central areas of the basin. Two types of diagenetic carbonates have been distinguished: (1) laminated diagenetic carbonates in which the original structure of sequences formed of laminated magnesite, dolomite and primary gypsum is preserved, though transformed in calcite; (2) brecciated diagenetic carbonates, which resulted from extensive dissolution of lenticular gypsum macrocrystals accompanied by dedolomitization processes of dolomite host rock. The replacement by calcite resulted from rapid transformation of evaporite deposits either at the contact of these deposits with overlying freshwaters or by percolating freshwater at very shallow burial depth. Stable isotope (carbon and oxygen) analyses of the diagenetic carbonates support influence of meteoric-derived carbonate-rich groundwater for their formation. The meteoric isotope signature is supported by its comparison with the stable isotope values determined from diagenetic calcites formed after magnesite in evaporite sequences during the Late Pleistocene and Holocene. The diagenetic carbonate bodies formed as a result of a progressive change from highly to moderately concentrated saline lake waters. This gradual evolution was related to a climatic shift from dry and hot to cooler and more humid conditions throughout the Miocene, a trend that has been also recognized in other large Tertiary basins of the Iberian Peninsula in this period.
\end{abstract}

Keywords: Calcitization; Diagenesis; Tertiary basin; Stable isotopes; Climatic change

* Corresponding author. Tel.: +34-91-520-1936; fax: +34-91520-1074.

E-mail address: sanzre@inta.es (E. Sanz-Rubio).

\section{Introduction}

Many ancient evaporite sequences formed of $\mathrm{Ca}$ sulphates (gypsum and anhydrite) show features indicative of partial or complete replacement by carbonate. Previous descriptions of diagenetic carbonates replacing sulphates in evaporite sequences deal with 
sedimentary deposits of marine origin or salt dome caprock formations (Kirkland and Evans, 1976; McKenzie et al., 1980; Pierre and Rouchy, 1988; Youssef, 1989; Rouchy et al., 1994) and ancient lacustrine deposits (Tucker, 1978; Bell, 1989; Anadón et al., 1992; Сан averas et al., 1996). Although bacterial sulphate reduction is the most commonly invoked mechanism for the transformation of sulphate to carbonate, leading usually to the formation of native sulphur deposits, not all replaced sulphate deposits result from this process (Anadón et al., 1992). As suggested by Wigley (1973), Rebelle (1987) and Pierre and Rouchy (1988), an alternative view is that sulphate replacement by calcite can also occur via reaction with carbonate-rich groundwater.

In addition, the replacement of Mg-Ca carbonates (dolomite) by calcite is a common feature in both ancient marine and continental evaporite sequences. A close relationship between evaporites and dedolomitization has been widely documented (Jacobs et al., 1982; Kastner, 1982; Budai et al., 1984; Canaveras et al., 1996; amongst others).

Most studies of diagenetic carbonates associated with evaporites deal either with replacement of $\mathrm{Ca}$ sulphates by calcite, generally in ancient sedimentary successions, or with calcitization of carbonate minerals, mainly magnesian carbonates, in modern to ancient saline lake deposits. Although the mineralogical composition of the diagenetic carbonates formed after Ca sulphates can consist of calcite, aragonite, dolomite, ankerite or magnesite, the former mineral is the most common (Rouchy et al., 1994). These transformations may have occurred in sedimentary sequences composed of an association of magnesian carbonates and calcium sulphate deposits. To date, only a few authors (e.g. Kirkland and Evans, 1976; Canaveras et al., 1996) have studied in detail the calcitization processes that have affected calcium sulphate and carbonate occurring together in a same evaporite succession.

The Miocene sedimentary record of the Calatayud Basin contains centimetre to metre-thick beds and large bodies of carbonates, mainly composed of low-magnesian calcite, that reach several decametres in thickness and display textural features, such as ghost and/or pseudomorphs of calcium sulphate crystals, microspar and pseudospar calcite mosaics, that mimic evaporite fabrics and structures. The diagenetic carbonates have been interpreted as a result of the transformation of previous mineral phases such as dolomite, magnesite and calcium sulphates (SanzRubio et al., 1998). This study deals with the description of the carbonate diagenetic fabrics present in the Miocene continental deposits of the Calatayud Basin and the interpretation of their origin. A sedimentary model relating calcitization processes to the evolution of the basin is presented.

\section{Geological setting}

The Neogene Calatayud Basin is an elongated NW-SE-oriented intermontane depression filled in its central part by an up to $1200 \mathrm{~m}$ thick succession of lacustrine and alluvial sediments (Fig. 1A). The sedimentary fill of the basin displays a concentric facies distribution with clastic deposits in the margins passing progressively into evaporites and carbonates towards the central part of the basin. Three main Miocene-Pliocene units (Lower, Intermediate and Upper), separated by two major sedimentary discontinuities, have been recognized in the basin (Hoyos and López-Martlıez, 1985; Sanz-Rubio et al., 1997).

The Lower Unit (Upper Oligocene-Middle Aragonian in age) (Fig. 1B and C) is composed of more than $500 \mathrm{~m}$ of evaporites in the central part of the basin. At the top of the Lower Unit, the saline deposits are composed mainly of anhydrite, gypsum and glauberite, with halite having been described in deep boreholes. Although no sodium-calcium sulphate (glauberite) and calcium sulphate minerals (anhydrite) are found at the surface, they appear to be replaced by secondary gypsum under near-surface conditions (Sánchez-Moral et al., 1993; OrtI and Rosell, 1994). In the central and southern parts of the basin, the uppermost part of the unit is composed of superposed 2-2.5 $\mathrm{m}$ thick sequences formed of rhythmic alternations of laminated gypsum (microselenitic, clastic and lenticular) alternating with thin magnesite/dolomite mudstones (Sanz-Rubio et al., 1997). Anhydrite/magnesite couplets are commonly present towards the margins of the basin at the transition between the Lower and Intermediate Units. The Intermediate Unit (Upper Aragonian-Lower Vallesian in age), up to $120 \mathrm{~m}$ in thickness, comprise mainly laminated gypsum and dolomite deposits which have been interpreted as indicative of 


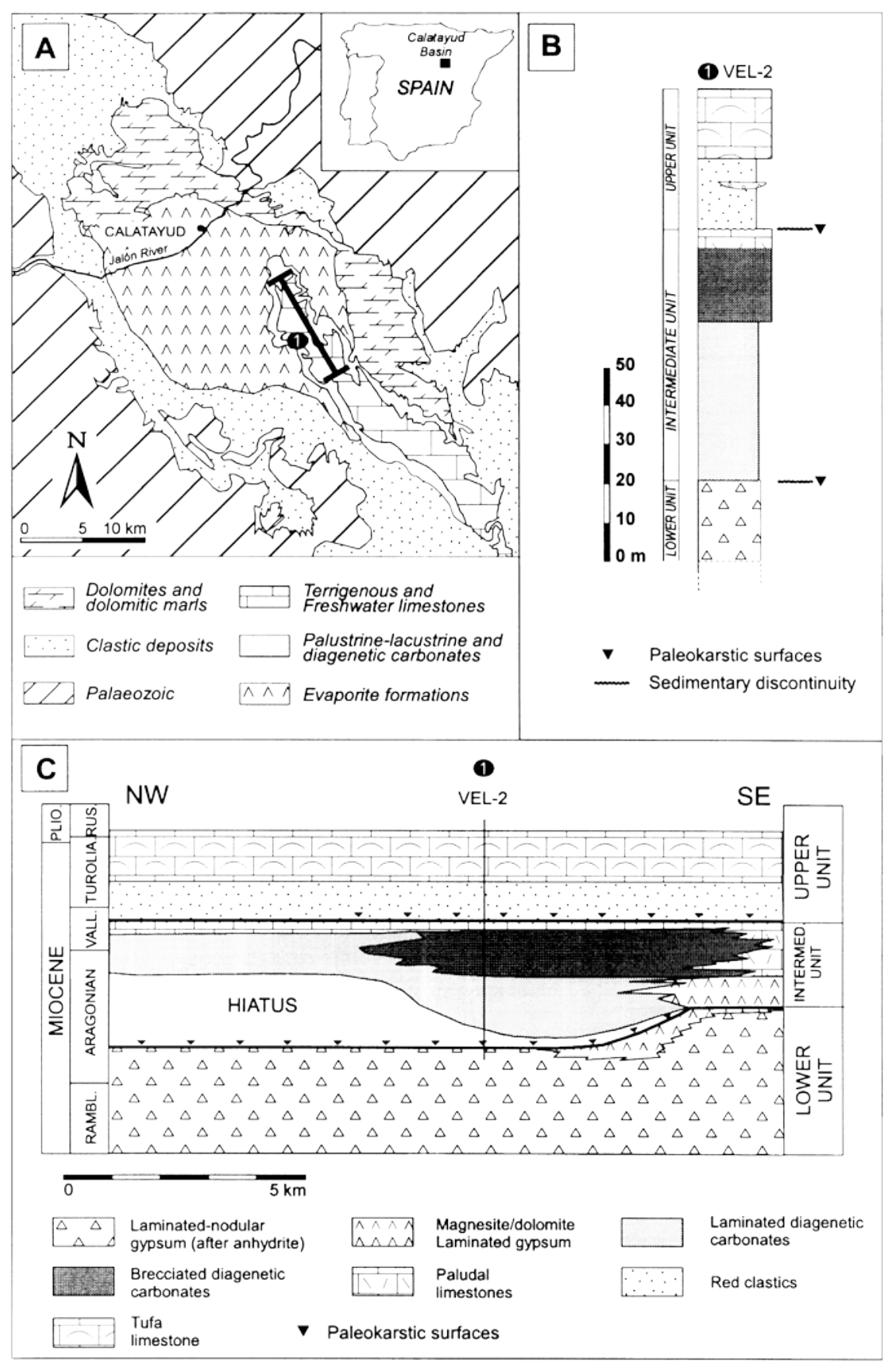

Fig. 1. (A) Schematic geological map of the Calatayud Basin with indication of the stratigraphic sketch represented in (C); the encircled number corresponds to the location of section VEL-2. (B) Lithostratigraphic log of section VEL-2 (see legend in (C)). (C) Stratigraphic cross-section showing the distribution of the main lithosomes in the central part of the Calatayud Basin (see location in (A)), thickness of the stratigraphic section not to scale. 
evaporitic deposition under shallow lake subaqueous conditions, associated laterally with extensive dolomitic mudflats (Sanz-Rubio et al., 1998). Diagenetic carbonate bodies resulting from calcitization of $\mathrm{Mg} /$ Ca carbonates and Ca sulphates are largely developed in central areas of the basin where they form locally most of the sedimentary succession belonging to the Intermediate Unit (Fig. 1B). Two main types of diagenetic carbonates, laminated and brecciated carbonates, have been distinguished. Their stratigraphic distribution is shown in Fig. 1C. The Upper Unit (Upper VallesianLower Ruscinian in age), ranging from 25 to $85 \mathrm{~m}$ in thickness, consists of terrigenous alluvial-fluvial deposits and fluvio-lacustrine carbonates.

The boundary between the Lower and Intermediate units is marked by a palaeokarstic surface in the central part of the basin, this providing evidence of an episode of subaerial exposure after the deposition of the evaporites of the Lower Unit. The boundary between the Intermediate and Upper units is marked by a sedimentary discontinuity where palaeokarstic features are also recognized and it is characterized by an extensive and net progradation of alluvial-fluvial deposits over lacustrine sediments, thus representing a major change in the palaeogeography of the basin (Hoyos et al., 1998). The latter discontinuity was related to an important regional tectonic event that has also been recognized in other continental Tertiary basins of the Iberian Peninsula (Calvo et al., 1993).

\section{Methods}

Integrated field observations, standard petrographical techniques and stable isotope analyses were used in this study. The distribution of the diagenetic carbonate bodies through the basin, their relations with the sedimentary discontinuities and the depositional features of the precursor deposits were first established by fieldwork. Sampling was focused on determining the textural and compositional characteristics of diagenetic carbonates from 20 selected sections of which section VEL-2 (Fig. 1B) was considered to be quite representative. Petrographic conclusions are based on the examination of more than 200 stained (alizarin red S and potassium ferricyanide) thin-sections by means of conventional polarized light. The mineralogy of the samples was determined using a Phillips XRD system operating at
$40 \mathrm{kV}$ and $30 \mathrm{~mA}$ with monochrome CuKa radiation. Mole percent magnesium carbonate in calcite was estimated by measuring the d104 spacing (Goldsmith and Graf, 1958) using quartz as an internal standard. Dr. C. Pierre performed the stable isotope analyses at the Stable Isotopes Laboratory of LODYC (University P. et M. Curie, Paris). The analysed samples were selected on the basis of petrographic and XRD studies. The samples were first washed with distilled water to eliminate the soluble salts and then dried. The isotopic composition of calcite was measured on the $\mathrm{CO}_{2}$ gas extracted after the total reaction of the carbonate with phosphoric acid at $25^{\circ} \mathrm{C}$. In mixed carbonates, the dolomite was first isolated by selective attack with $1 \mathrm{~N}$ acetic acid for $20 \mathrm{~min}$ and later reacted with phosphoric acid at $25^{\circ} \mathrm{C}$ for 4 days. The $\mathrm{CO}_{2}$ extracted from the mixtures after 20 min of reaction with phosphoric acid was considered to come mainly from calcite. The resulting $\mathrm{CO}_{2}$ gas was analysed on a triple collector mass spectrometer (VG-SIRA 9). The results are expressed by conventional notation relative to the PDB standard. For the dolomites, the $o^{18} \mathrm{O}$ values are corrected by 0.80 for the fractionation effect during the phosphoric acidreaction(Sharma and Clayton, 1965).

\section{Petrology and occurrence of thediagenetic carbonates}

We use the term "diagenetic" exclusively for sedimentary bodies of calcite with crystalline fabrics which exhibit replacement features from former carbonates and sulphates. Diagenetic carbonates are relatively abundant throughout the basin, particularly in the Intermediate Unit where they are basically associated with the two major sedimentary discontinuities recognized in the Tertiary succession (Fig. 1C). The diagenetic carbonates constitute decametre-thick, laterally large bodies with irregular bases and planar tops. Only some centimetre-thick beds of these carbonates can be recognized towards the uppermost part of the Lower Unit. Two main types of diagenetic carbonates, laminated and brecciated, can be distinguished.

\subsection{Laminated diagenetic carbonates}

They comprise finely laminated carbonate beds formed of alternating clear-porous calcite and darkhomogeneous calcite laminae. The average thickness 



Fig. 2. (A) Outcrop view of laminated diagenetic carbonates of the Intermediate Unit overlying laminated gypsum of the Lower Unit. White arrows point the contact between both units. Bar $=0.5 \mathrm{~m}$. (B) Outcrop view of the brecciated diagenetic carbonates from the top of the Intermediate Unit showing their characteristic rubber-like chaotic aspect. White arrows show the lower boundary for the diagenetic alteration. Below the boundary, unaltered dolomite deposits with macrolenticular gypsum are predominant in the thicker tabular beds shown in the middle of the photograph (see person for scale).

of the laminae is $0.5 \mathrm{~cm}$. The carbonates preserve depositional structures, i.e. lamination, wave and current ripples, relics of gypsum crystal habits and textures, and deformation fabrics typical of competitive growth of gypsum crystals, which are quite similar to those shown by sequences formed of primary gypsum that frequently underlie the carbonates (Fig. 2A). Soft sediment deformation (slump structures from millimetre to metre scale) and intense microfaulting, indicative of collapse of underlying gypsum formations, are also commonly observed.

Locally, some fine-grained clastic carbonate hori- zons interlayered in tabular bodies of diagenetic carbonate beds have been identified. Their lithological composition reveals reworking and alteration of lithified diagenetic carbonates.

The laminated carbonates show textures dominated by alternating microspar and pseudospar laminae (Fig. 3A and B). Microspar laminae are characterized by cloudy xenotopic calcite mosaics $(5-30 \mu \mathrm{m})$ with abundant impurities, organic matter, siliciclastic grains, plant remains, Fe-oxides and authigenic silica crystals. Pseudospar laminae are composed of clean xenotopic calcite mosaics $(100-150 \mu \mathrm{m})$ and/or 

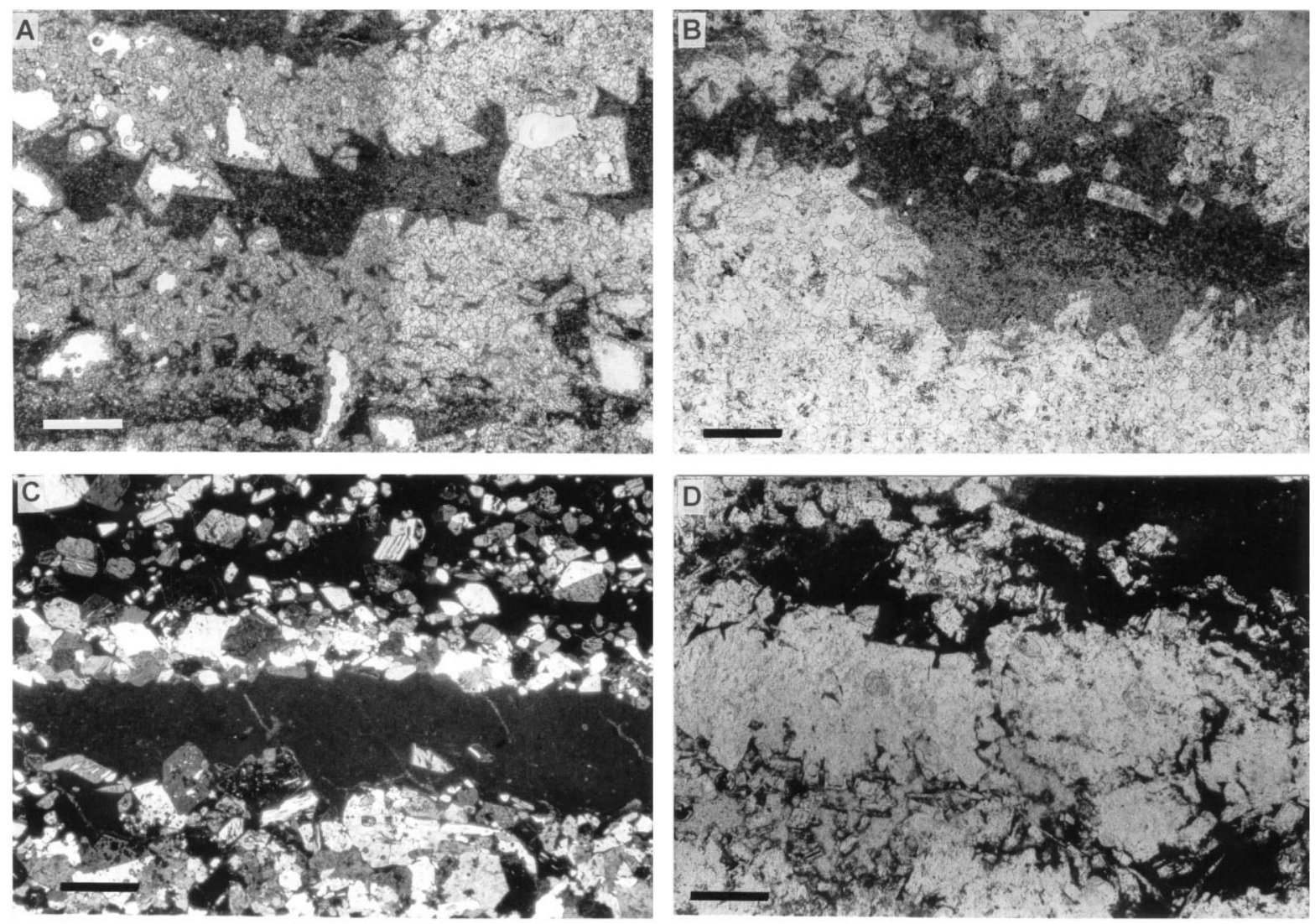

Fig. 3. (A) Calcitized primary gypsum/magnesite-dolomite couplets from the Intermediate Unit (plane polarized light). Scale bar $=1 \mathrm{~mm}$. (B) Calcitized anhydrite/magnesite couplets from the Lower Unit (plane polarized light). Scale bar $=1 \mathrm{~mm}$. (C) Primary gypsum/magnesite-dolomite couplets from the Intermediate Unit (cross polarized light) Scale bar $=1 \mathrm{~mm}$. (D) Anhydrite/magnesite couplets from the Lower Unit (plane polarized light). Scale bar $=1 \mathrm{~mm}$. Textural similarities can be noted when photomicrographs (A) and (C), and (B) and (D) are compared, as they correspond in each case to calcitization products and their precursors. 
aggregates of sub-rhombic calcite crystals similar in size. Both microspar and pseudospar laminae show gradation in crystal size. Frequently, the replacement textures permit the identification of well-defined ghosts and/or pseudomorphs of calcium sulphate crystals, either gypsum (Fig. 3A) or anhydrite (Fig. 3B).

Microspar laminae are interpreted as resulting from calcitization of previous $\mathrm{Mg}$ and $\mathrm{Mg}$-Ca carbonate enriched muds (magnesite or dolomite) whereas pseudospar mosaics were formed by the replacement of calcium sulphate laminae by calcite (Sanz-Rubio et al., 1998). The petrographic study allows to distinguish two major diagenetic lithofacies, which are replacement products of either primary gypsum/ magnesite-dolomite couplets (Fig. 3C) or anhydrite/ magnesite (Fig. 3D).

Most of the laminated carbonate bodies are interpreted as the result of calcitization or calcite void filling of rhythmic alternations of layered primary gypsum (microselenitic, clastic and lenticular) and thin magnesite/dolomite mudstone (Fig. 3A). Calcitized anhydrite/magnesite couplets are commonly present as isolated centimetre-thick beds at the transition between Lower and Intermediate Units (Fig. 3B). Although in these diagenetic materials microspar laminae represent calcitization of magnesite/dolomite carbonates, we have observed that the replacement of layered gypsum results in two main microtextures: (a) homogenous pseudospar and (b) aggregates of subrhombohedric calcite crystals with either cloudy or clean cores. The aggregates of sub-rhombohedric calcite crystals (100-150 $\mu \mathrm{m}$ in length) forming porous and heterogeneous fabrics can be clearly identified as a result of the replacement of gypsum laminae by calcite.

\subsubsection{Occurrence}

The laminated diagenetic carbonates are widespread throughout the Calatayud Basin, particularly in the Intermediate Unit where they form up to $60 \mathrm{~m}$ thick carbonate bodies in central parts of the basin (Fig. 1B). The carbonates always overlie calcium sulphates of the Lower Unit and frequently underlie brecciated diagenetic carbonates or unaltered dolomite deposits towards the top of the Intermediate Unit (Fig. 2B).

The boundary between the Lower Unit and the diagenetic carbonates of the Intermediate Unit is commonly marked by a well-defined palaeokarstic surface on top of gypsum deposits of the Lower Unit, which locally appears as a very irregular relief (Fig. 4A and B). The gypsum deposits of the Lower Unit are usually composed of both secondary gypsums after anhydrite with minor glauberite and thin alternations of primary gypsum and magnesite (Sanz-Rubio et al., 1997; Hoyos et al., 1998). The palaeokarstic surface displays the following features:

(a) Presence of vadose exokarstic morphologies, e.g. infilled sinkholes, at the top of the Lower Unit (Fig. 5A).

(b) Solution-induced subsidence and collapses of the overlying sediments into the sinkholes (Fig. 5B). This process could be repeated through several evolutionary stages of the basin, as evidenced by the fact that some collapses affect the Upper Unit (Fig. 5C).

(c) Development of discontinuities and low-angle unconformities between the gypsum of the Lower Unit and the overlying diagenetic carbonates (Fig. 5B).

(d) Presence of synsedimentary deformation structures, e.g. slumps, changes in the thickness of strata, accompanied by reworking of carbonates. The deformation was prior to lithification of the carbonate, which can be seen accommodated in karstic gypsum depressions (Fig. 5D).

Detailed petrographic and geochemical studies were carried out in the gypsum deposits affected by the paleokarstic surface and the diagenetic carbonates just above the discontinuity. This showed that mixed samples (gypsum/magnesite and calcite) are uncommon. Below the discontinuity surface, calcite is a minor mineral phase and only scarce and partial replacements affecting gypsum and magnesite were observed; however, above the discontinuity, calcite is frequently the unique mineral phase, and only minor percentages of gypsum and magnesite are detected in the first metres above the paleokarstic surface by means of XRD.

In places where the palaeokarstic features are not so evident, the sedimentary discontinuity between the Lower and Intermediate units is defined by a drastic change in lithology. Thus, the evaporite deposits of the Lower Unit are commonly composed of secondary 


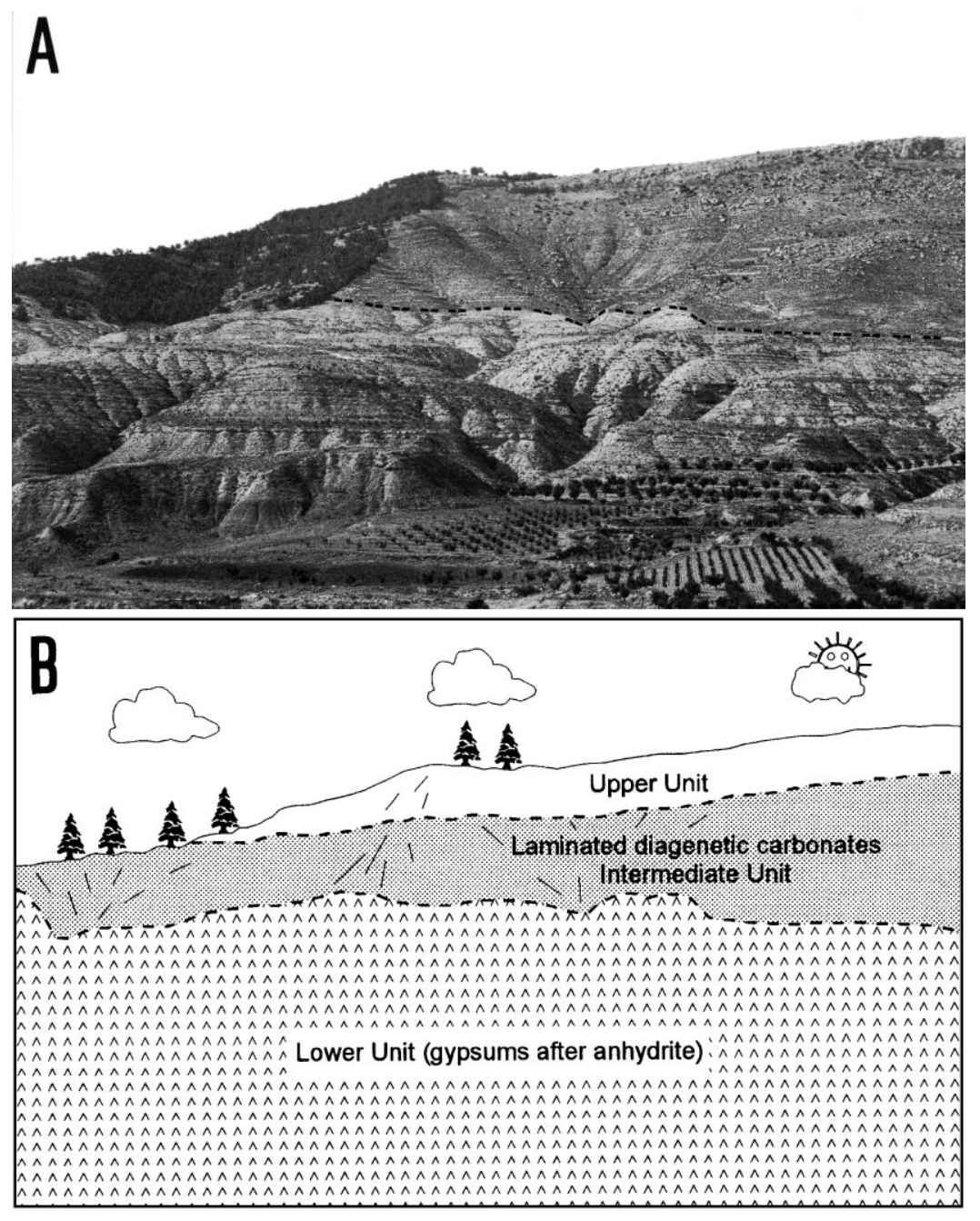

Fig. 4. (A) Outcrop view of the sedimentary discontinuity between the evaporites of the Lower Unit and the overlying diagenetic carbonates of the Intermediate Unit; note the markedly irregular surface of the contact. (B) Line drawing explicative of the stratigraphic relationship of the deposits shown in the upper photograph.

gypsum after anhydrite and minor amount of glauberite, with the exception of the southern part of the basin where the evaporite deposits consist of mixed laminated primary gypsum and magnesite. In this case, the sedimentary discontinuity between the two units can be traced underlying the laminated diagenetic carbonate strata.

\subsection{Brecciated diagenetic carbonates}

They comprise well-defined tabular- to wavy- shaped beds mixed with tabular- to irregular-shaped bodies of clast-supported breccias resulting in a characteristic rubber-like chaotic aspect (Fig. 2B). Two main fabric types can be differentiated in these carbonates:

(1) Xenotopic mosaics of pseudospherulitic fi calcites that consist of individual sphaeroidal to elliptical crystals, generally exhibiting irregular faces and displaying an internal fibrous microfabric. Similar fabrics have been previously described by Rossi and Canaveras (1999) in the Tertiary of 

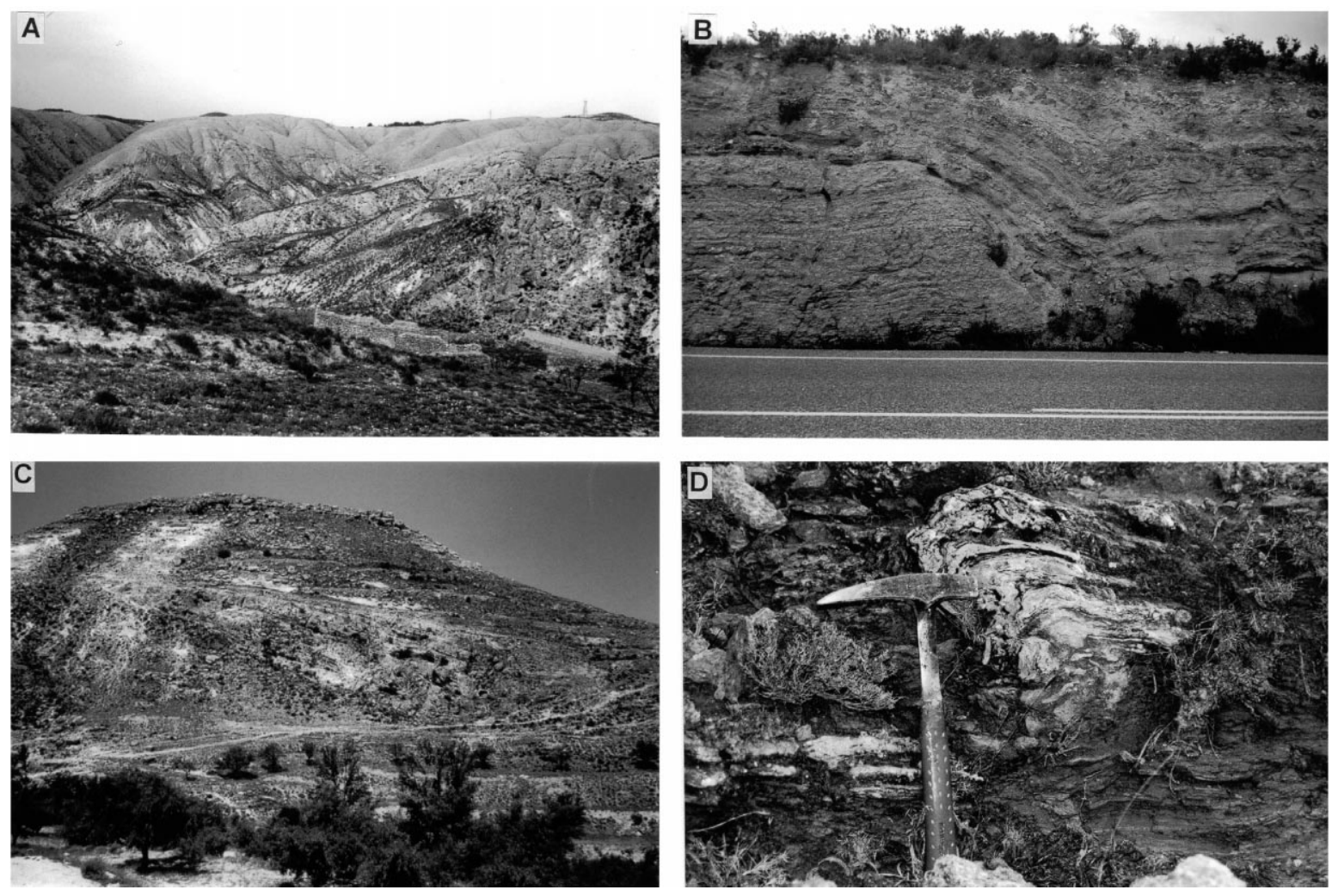

Fig. 5. (A) Collapse structure in the Lower Unit gypsum. The deposits of the Intermediate and Upper units crop out inside the collapse. (B) Small-scale collapse structure developed in gypsum of the Lower Unit and further accommodation of the diagenetic carbonates of the Intermediate Unit. Towards the left side of the photo, a low angle unconformity between the Lower Unit gypsum and the overlying diagenetic carbonates of the Intermediate Unit can be observed. (C) View of a progressive discordance in lacustrine carbonate deposits of the Upper Unit due to the subsidence induced by late karstification processes affecting to the underlying gypsum of the Lower Unit. (D) Close-up view of a slump structure affecting laminated diagenetic carbonates.

the Madrid and Ager basins in Spain. Ghosts of lenticular gypsum crystals are commonly preserved. Palisades composed of parallel fi ous calcite have also been recognized within the mosaics of pseudospherulitic calcites (Fig. 6A). Pseudospherulitic calcites are related to stratiform clast-supported breccias and diagenetic carbonates formed during early karstifi stages.

(2) Sutured calcites are composed of xenotopic mosaics of calcite crystals predominantly with serrated or irregular intercrystalline boundaries. Ghosts and/or calcite pseudomorphs of lenticular gypsum crystals are disseminated throughout the mosaics (Fig. 6B). The boundaries of the former gypsum crystals may be traced inside the calcite mosaics indicating the replacement affected simulta- neously to the gypsum crystals and their matrix. Sutured calcites are intimately associated with pseudospherulitic fibrous calcites.

Some important observations have to be taken into account in the genetic interpretation of these fabrics: (1) all the dolomites reported are crypto-microcrystalline in size and are interpreted as primary or early diagenetic (Sanz-Rubio et al., 1999); (2) an abrupt contact between calcitized dolomites and non-calcitized dolomicrites with gypsum crystals can be commonly observed at outcrop scale; and (3) dolomite relics are identified as cloudy areas in spar calcite crystals in thin sections, which is also determined by XRD. Previous studies in other continental Tertiary Iberian basins have interpreted these fabrics as a result of early-diagenetic replacive/displacive growth of 

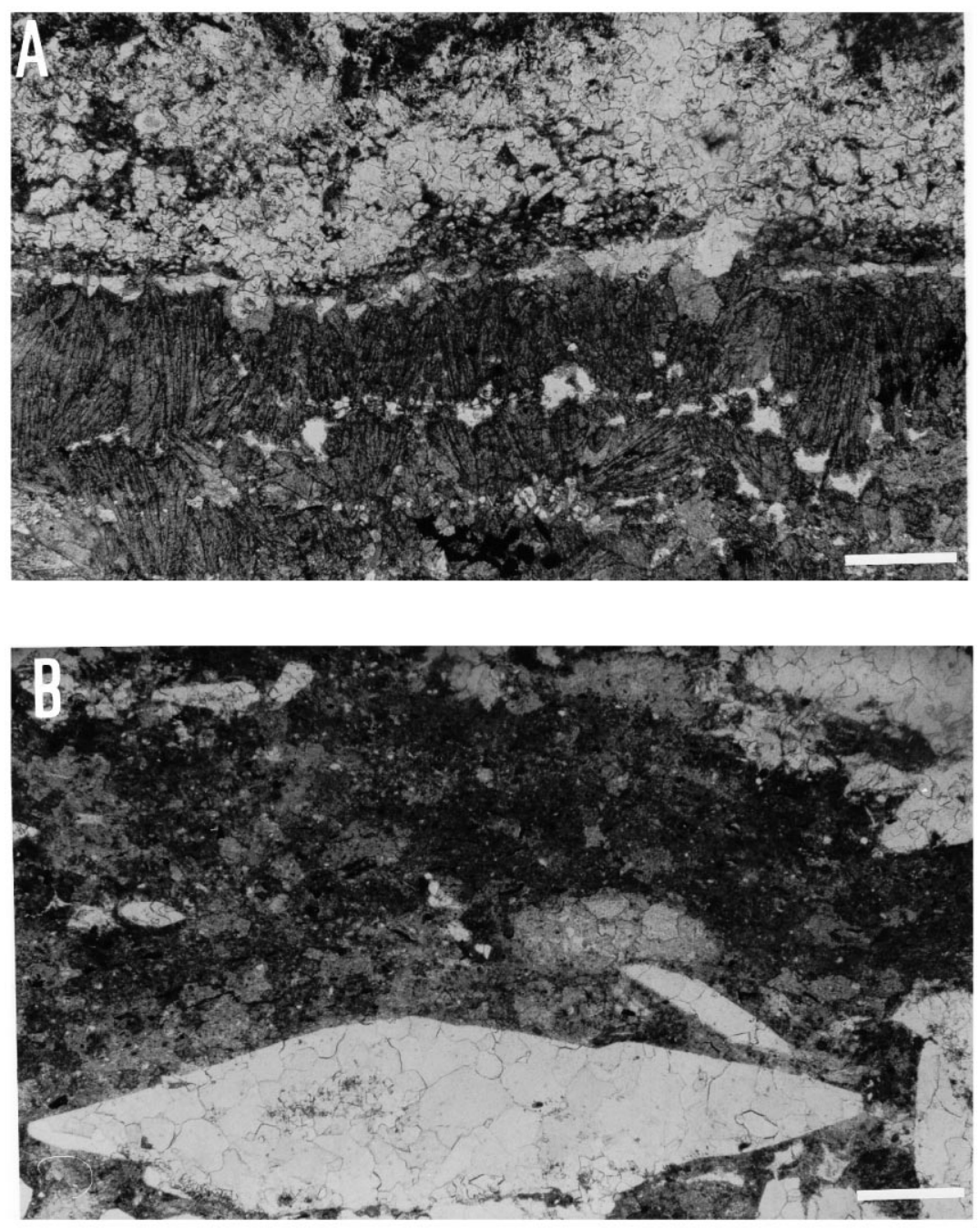

Fig. 6. Photomicrographs showing textures recognized in the brecciated diagenetic carbonates: (A) Palisades of parallel pseudospherulitic fibrous calcite crystals (lower part of the picture). The upper part of the photograph shows calcite mosaics due to replacement of dolomite (cross polarized light). Scale bar $=1 \mathrm{~mm}$. (B) Mosaic of sutured calcite crystals (darker ground of the photograph) containing some ghosts and/or calcite pseudomorphs of lenticular gypsum (cross polarized light). Scale bar $=1 \mathrm{~mm}$.

calcite crystals within dolomicrite host sediments (Can averas et al., 1996; Rossi and Canaveras, 1999). In the same way, non-fabric, selective dedolomitization after a dolomicrite precursor can be invoked for the pseudospherulitic fibrous and sutured calcite fabrics from the Calatayud Basin (Sanz-Rubio et al., 1998; Sanz-Rubio, 1999).

\subsubsection{Occurrence}

The brecciated diagenetic carbonates form thick sequences towards the top of the Intermediate Unit, beneath the stratigraphic discontinuity that separates this unit from the Upper Unit (Fig. 1B and C). They are restricted to the central and southern parts of the basin and pass laterally into the previously described strata of laminated diagenetic carbonate. The presence of widespread laterally continuous collapse breccias as well as the abundance of calcitization fabrics after gypsum, i.e. gypsum pseudomorphs and boxwork structures, are features indicative of 

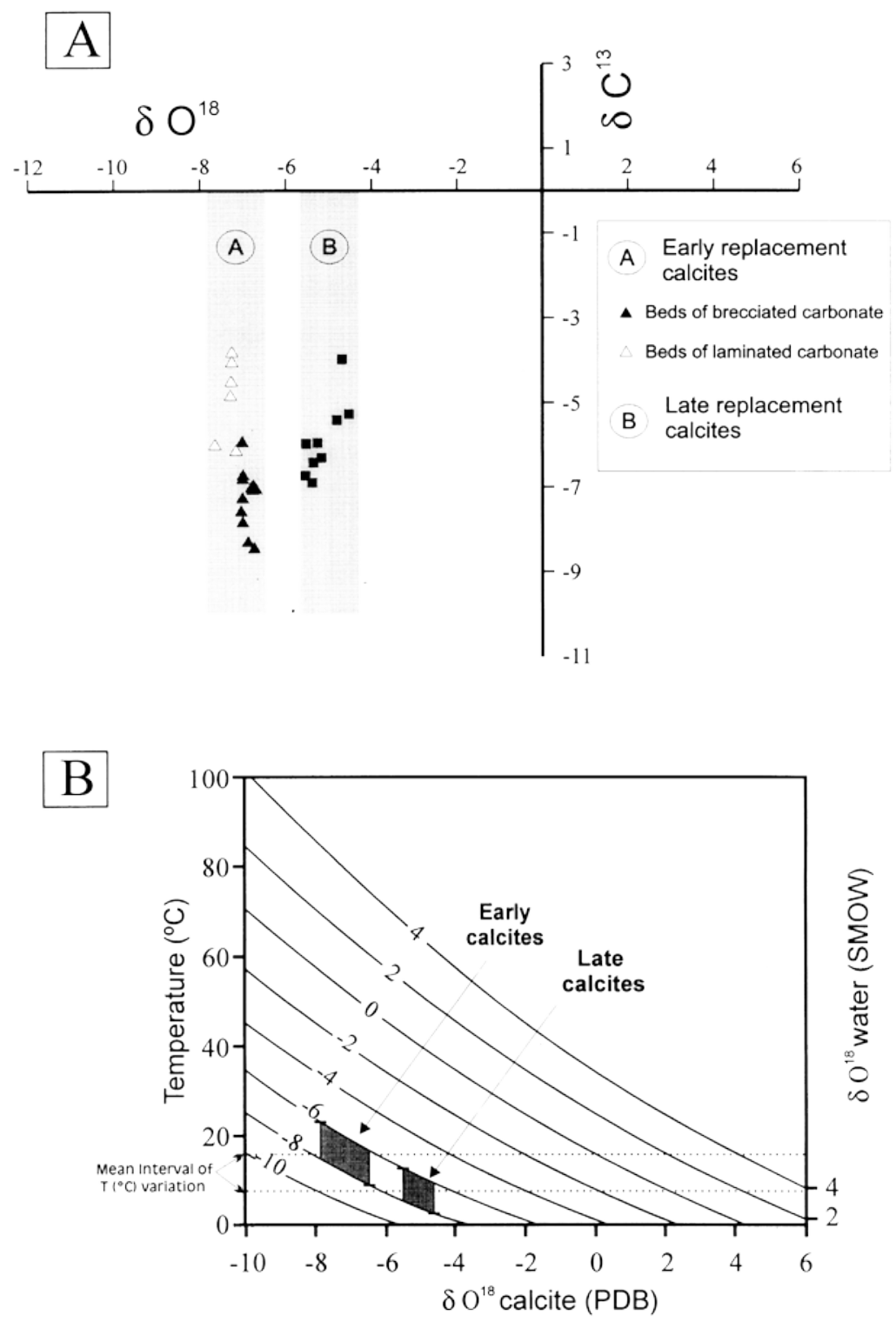

Fig. 7. (A) Stable isotopic compositions (oxygen and carbon) from calcites present in the diagenetic carbonates of the Calatayud Basin; in the cross-plot, two groups of samples are discriminated that correspond to early and late replacement calcites, respectively. Moreover, two subgroups are distinguished in early replacement calcites because their relation with beds of laminated carbonate or brecciated carbonate. (B) Calculation of the temperature ranges for the two groups of isotope values using the fractionation curves of Friedman and O'Neil (1977) (see text). The difference of temperature of about $8^{\circ} \mathrm{C}$ is estimated taking into account the mean of temperature intervals of each group. 
pervasive replacement of prior interbedded and associated sulphates. Both the location of the brecciated carbonate and the fabrics exhibited by the carbonates strongly suggest that their formation was related to subaerial exposure and associated karstifi ation phenomena. This resulted in a complex history of dissolution, collapse and infi ng processes with typical karst products, such as caves, collapse breccia and speleothems that extend locally up to $45 \mathrm{~m}$ downwards below the discontinuity. Partially dedolomitized materials and paludal limestones can also be recognized in the host rock (Fig. 2B). The fabrics observed in the brecciated carbonate formed by calcitization of earlier dolomites and dolomitic marls with intrasedimentary macrolenticular gypsum.

\section{Stable isotope geochemistry}

The study of stable isotopic signatures of both laminated and brecciated diagenetic carbonates sampled in section VEL-2 and other outcrops in the basin has been complemented with the analysis of late diagenetic calcites formed after magnesite during the Late Pleistocene and Holocene (Canaveras et al., 1998). The comparison of both sets of data allows a better understanding of the calcitization processes that took place during the evolution of the basin. As a whole, the replacive calcites show, in general, moderately low isotopic compositions characteristic of meteoric near-surface diagenesis. $O{ }^{18} \mathrm{O}$ values reveal the existence of two well differentiated groups of diagenetic calcites (Fig. 7A, Table 1):

(1) Group A (Fig. 7A): diagenetic calcites belonging to this group have low $o^{18} \mathrm{O}$ values (from -7.8 to -6.50 PDB). The petrographic features of these calcites, together with their stratigraphic relationship with non-replaced evaporite deposits, indicate that they formed by early replacement of dolomite, gypsum and/or magnesite. In addition, two sub-groups can be differentiated (Fig. 7A): one corresponds to calcites from diagenetic laminated carbonates $\left({ }^{18} \mathrm{O}\right.$ values ranging from -7.8 to $-7.20 \mathrm{PDB}$ and $o{ }^{13} \mathrm{C}$ values between -6.2 to $-3.50 \mathrm{PDB}$ ) and the other sub-group corresponds to calcites from brecciated diagenetic carbonates $\left(o^{18} \mathrm{O}\right.$ values ranging from -7 to $-6.50 \mathrm{PDB}$ and $o^{13} \mathrm{C}$ values between -8.5 to
-60 PDB). All calcites included in group A formed through early diagenetic replacements and represent the scope of this work.

Isotopic analyses of pure dolomite and mixed dolomite-calcite samples collected in adjacent deposits of the Intermediate Unit show a wide range of $o^{18} \mathrm{O}$ and $o^{13} \mathrm{C} \quad$ values $\quad\left(-5.50<o^{18} \mathrm{O}<-10 \quad \mathrm{PDB}\right.$; $-4.50<o^{13} \mathrm{C}<-0.20$ PDB) (Sanz-Rubio, 1999) which are characteristic of moderate saline lacustrine sedimentation. Moderately negative $o{ }^{18} \mathrm{O}$ values indicate that evaporative concentration of water was not a dominant process in the lake, as would be deduced from dolomites with more positive $o{ }^{18} \mathrm{O}$ values (Last, 1990; Anadòn and Utrilla, 1993).

(2) Group B (Fig. 7A): samples of this group correspond to diagenetic calcites interpreted as formed by late replacement of magnesite (Canaveras et al., 1998). These calcites are characterized by more positive $o{ }^{18} \mathrm{O}$ values (from -5.5 to $-4.60 \mathrm{PDB}$; mean -5.10) whilst they show a wider range of $o^{13} \mathrm{C}$ values, from -6.9 to -40 PDB. Magnesites occurring in the Miocene successions of the Calatayud Basin show typically high, although varied, $o^{18} \mathrm{O}$ values (4.9 to - 1.60 PDB) and $o^{13} \mathrm{C}$ values ranging from -7.9 to -6.50 PDB (Canaveras et al., 1998). The high $o^{18}$ Ovalues of the magnesites suggest precipitation under strong evaporitic conditions, which is in agreement with those concluded by Kralik et al. (1989) from similar lacustrine magnesites. The moderately low $o^{13} \mathrm{C}$ values can be interpreted as resulting from waters enriched in soil-derived organic carbon although mechanisms of bacterial sulphate reduction (BSR) cannot be ruled out. Similar $o^{13} \mathrm{C}$ values have been measured on bulk calcites resulting from BSR processes in the restricted marine Lorca Basin (SE Spain) (Rouchy et al., 1998) as well as in the Miocene lake deposits of the Teruel Basin (Anadón et al., 1992), although $o^{13} \mathrm{C}$ values determined from calcites produced by BSR elsewhere are usually very negative (Kirkland and Evans, 1976; Bellanca et al., 1986; Decima et al., 1988; Pierre and Rouchy, 1988). BSR mechanisms imply the availability of large amounts of labile organic matter used by bacteria as energy source. The sedimentary succession of the Calatayud Basin is characterized by the scarcity of the organic matter and the lack of any sedimentological evidence of meromictic conditions with anoxic bottom conditions. Moreover, 
Table 1

Samples, description and stable isotopic compositions of calcites (oxygen and carbon) from the diagenetic carbonates of the Calatayud Basin. Cal, calcite; Dol, dolomite; Mag, magnesite; Gyp, gypsum; Cel, celestite; Phy, phyllosilicates; Q, quartz. Stable isotopes are given in the delta notation with respect to PDB

\begin{tabular}{|c|c|c|c|c|c|c|c|c|c|c|c|}
\hline Sample & Diag. stage & Carbonate type & Cal & Dol & Mag & Gyp & Cel & Phy & $\mathrm{Q}$ & $o^{18} \mathrm{O}$ & $o^{13} \mathrm{C}$ \\
\hline Mar-2.5 & Early & Calcite with lenticular gypsum & 32 & & & 9 & & 22 & 37 & -7.38 & -4 \\
\hline Mar-2.7A & Early & Laminated calcite & 88 & & & & 9 & & 3 & -7.36 & -4.41 \\
\hline Mar-2.7B & Early & $\begin{array}{l}\text { Laminated calcite with gypsum } \\
\text { pseudomorphs }\end{array}$ & & & & & 9 & & 2 & -7.4 & -4.77 \\
\hline Mar-2.9 & Early & $\begin{array}{l}\text { Massive calcite with } \\
\text { pseudomorphs }\end{array}$ & 92 & & & & 8 & & & -7.15 & -6.12 \\
\hline Mar-2.11 & Early & Laminated calcite & 65 & & & & & 25 & 10 & -7.64 & -6.05 \\
\hline Mar-2.13 & Early & Peloidal calcite & 97 & & & & & & 3 & -6.93 & -6.07 \\
\hline Mar-2.14 & Early & Laminated calcite & 97 & & & & & & 3 & -6.87 & -8.31 \\
\hline Mar-2.15 & Early & Laminated calcite & 77 & 20 & & & & & 3 & -6.7 & -8.44 \\
\hline Mar-2.16 & Early & Nodular calcite & 98 & & & & & & 2 & -7.08 & -6.7 \\
\hline Mar-2.18 & Early & Laminated calcite & 77 & 21 & & & & & 2 & -7.1 & -7.59 \\
\hline Mar-2.20 & Early & Massive calcite & 100 & & & & & & & -6.81 & -7.01 \\
\hline Vel-2.2 & Early & Tabular calcite & 90 & & & & 10 & & & -7.33 & -3.77 \\
\hline Vel-2.5 & Early & Massive calcite & 99 & & & & & & 1 & -6.95 & -7.7 \\
\hline Vel-2.6 & Early & Laminated calcite & 85 & 13 & & & & & 2 & -6.84 & -7.1 \\
\hline Mar-3.12 & Early & Recrystallized calcite & 92 & 5 & & & & & 3 & -7.02 & -6.83 \\
\hline Mar-3.15 & Early & $\begin{array}{l}\text { Dolomicrite with gypsum } \\
\text { pseudomorphs }\end{array}$ & 56 & 42 & & & & & 1 & -7.03 & -7.15 \\
\hline Mar-3.18 & Early & Laminated calcite & 100 & & & & & & & -6.77 & -6.94 \\
\hline Kar-1 & Late & Magnesite replaced by calcite & 87 & & & & & 11 & 2 & -5.74 & -5.93 \\
\hline SR1-3 & Late & $\begin{array}{l}\text { Magnesite partially replaced by } \\
\text { calcite between nodular gypsum }\end{array}$ & 10 & & 60 & & & 27 & 3 & -5.4 & -6.9 \\
\hline SR1-4 & Late & $\begin{array}{l}\text { Magnesite partially replaced by } \\
\text { calcite between nodular gypsum }\end{array}$ & 24 & & 52 & 2 & & 19 & 3 & -5.4 & -6.9 \\
\hline SR1-5 & Late & $\begin{array}{l}\text { Magnesite partially replaced by } \\
\text { calcite between nodular gypsum }\end{array}$ & 52 & & 34 & & & 12 & 2 & -5.5 & -6.7 \\
\hline SR1-6 & Late & $\begin{array}{l}\text { Magnesite partially replaced by } \\
\text { calcite between nodular gypsum }\end{array}$ & 61 & & 26 & 1 & & 10 & 2 & -4.8 & -5.3 \\
\hline SR1-7 & Late & $\begin{array}{l}\text { Magnesite partially replaced by } \\
\text { calcite between nodular gypsum }\end{array}$ & 68 & & 29 & 1 & & & 2 & -5.2 & -5.9 \\
\hline SR1-8 & Late & $\begin{array}{l}\text { Magnesite partially replaced by } \\
\text { calcite between nodular gypsum }\end{array}$ & 81 & & 14 & & & & 5 & -4.6 & -5.2 \\
\hline SR2-3 & Late & $\begin{array}{l}\text { Magnesite partially replaced by } \\
\text { calcite between nodular gypsum }\end{array}$ & 48 & & 40 & & & 9 & 3 & -5.3 & -6.4 \\
\hline SR2-4 & Late & $\begin{array}{l}\text { Magnesite partially replaced by } \\
\text { calcite between nodular gypsum }\end{array}$ & 53 & & 28 & & & 15 & 4 & -4.7 & -4.0 \\
\hline
\end{tabular}

native sulphur or sulphides, commonly formed as by-products of BSR processes, are absent in the lake deposits of the Calatayud Basin, in contrast to those present in other Iberian Miocene lacustrine systems where BSR processes occurred (Servant-Vildary et al., 1990; Anadón et al., 1992). Considering these arguments together, they would favour for processes of replacement induced by meteoric waters enriched in soil-derived $\mathrm{CO}_{2}$ instead driven by bacterial sulphate reduction.
The two groups exhibit a similar range of variation of $o{ }^{13} \mathrm{C}$ values which indicates that in both cases the inorganic carbon reservoir was the same. In contrast, the $O{ }^{18} \mathrm{O}$ values of the replacing calcites are well discriminated with a difference of 20 between the two groups (Fig. 7A). Water concentration by evaporation is unlikely to have been the controlling factor for these differences as calcites of group A, representative of early diagenetic carbonates in which precipitation from more saline waters could 
be expected, are in fact characterized by lighter $O{ }^{18} \mathrm{O}$ values. Moreover, there is no geological evidence for a substantial burial depth of these deposits. Thus, keeping in mind the similarities of the precursor materials and the resulting calcitization fabrics and mineralogies, even the stable isotope pattern, shown by the early and late calcite replacements, we assume that they formed under similar shallow meteoric diagenetic conditions. The 20 difference observed in the $o{ }^{18} \mathrm{O}$ values could be explained simply by the effect of changes in temperature driven by climate.

Estimates of the water temperatures could be approached considering that the $o^{18} \mathrm{O}$ values of the calcite correspond to those predicted for calcite precipitated in equilibrium with meteoric waters in climatic conditions comparable to those of the Calatayud Basin during the Middle Miocene. Climate conditions of this inland area for the time involved are not precise, but it is assumed that during the Middle Miocene the world climate recorded a global change towards cooler and more humid conditions (Van der Meulen and Daams, 1992; Flower and Kennett, 1993; Krijgsman et al., 1994). Although it is improbable that the present-day climate of Central Spain strictly reflects that of the Middle Miocene, it can be noted that it is characterized by semi-arid conditions still resulting in the development of some evaporitic settings. $o{ }^{18} \mathrm{O}_{\text {SMOW }}$ values measured from the present-day meteoric waters in the Madrid Basin, central Spain, which are comprised between -6 and -80 (International Atomic Energy Agency, 1992) may be used as a rough approximation for a tentative evaluation of the variation of temperature indicated by the difference of $o{ }^{18} \mathrm{O}$ between the two groups of calcite. Using the equation of meteoric water ${ }^{18} \mathrm{O}_{\text {SMOW }}$ vs. ${ }^{18} \mathrm{O}_{\text {CALCITE }}$ of Friedman and $\mathrm{O}$ 'Neil (1977) and the $O{ }^{18} \mathrm{O}_{\text {SMOw }}$ value measured (Fig. 7B), a difference in temperature of about $8^{\circ} \mathrm{C}$ (using mean values of the temperature intervals for each isotopic group) should be obtained. This difference corre- sponds to a decrease from the first to the second group of $o{ }^{18} \mathrm{O}$ values of calcites; this is in the range of the expected temperature, respectively, for early replacement processes induced by the dilution of surficial shallow lacustrine waters (first group) and for an aquifer in which late replacement occurred (second group). Moreover, this is consistent with a global climate cooling recorded through this time interval. In the same sense, the observed differences for the two sub-groups of the early calcites could be also explained as a result of a progressive change of water temperature, which is mainly reflected in mineralogical changes in the precursor.

\section{Geneticmodel for thediagenetic carbonates}

The occurrence and spatial distribution of laminated and brecciated diagenetic carbonates in the Intermediate Unit of the Calatayud Basin seem to be indicative that these carbonates were generated under different diagenetic conditions. Both their stable isotope compositions and petrographic features reveal (i) differences in the calcitization mechanisms, (ii) variations of the environmental constrains, i.e. the temperature and geochemistry of the diagenetic fluids involved in the formation of the carbonates at the time of the carbonate crystallization, and (iii) close relationships with hydrochemical changes that characterize the sedimentary evolution of the basin.

\subsection{Calcitization mechanisms}

Dolomite and magnesite are the two main carbonate minerals after which the diagenetic carbonates formed. These carbonate minerals are always associated with calcium sulphate in the precursor deposits. The calcitization processes were especially active during the Middle Miocene when the lake waters were progressively changing from saline to more dilute towards the top of the Intermediate Unit.

Fig. 8. Sketch showing the sedimentary evolution of the Calatayud Basin during the Middle Miocene. Stages A and B correspond to the exhumation of the evaporite formations and development of a palaeokarstic surface related to the subaerial exposure of the evaporite deposits of the Lower Unit. Stage C corresponds to the deposition of laminated facies consisting of primary gypsum/magnesite-dolomite carbonates in the more rapidly subsiding and karstified gypsiferous areas. Increasing input of meteoric waters induced synsedimentary-early calcitization (polyphase calcitization) of the Intermediate Unit sediments in the subsiding areas. Stages D and E illustrate the maximum thickness reached up by the diagenetic carbonates in the collapsed-karstified-subsident areas and the final fossilization of the paleorelief (see text for detailed explanation of the successive stages). 
A
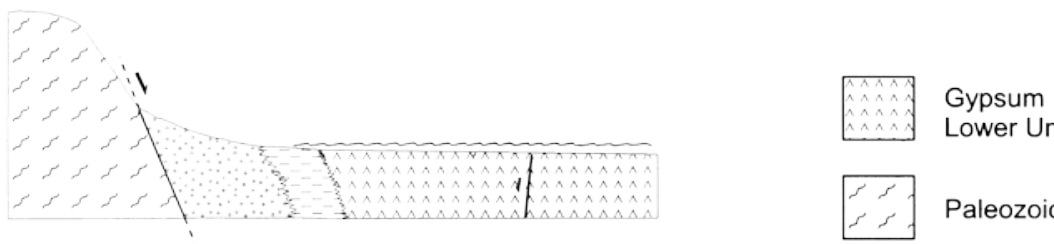

Lower Unit

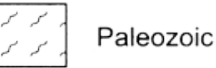

B
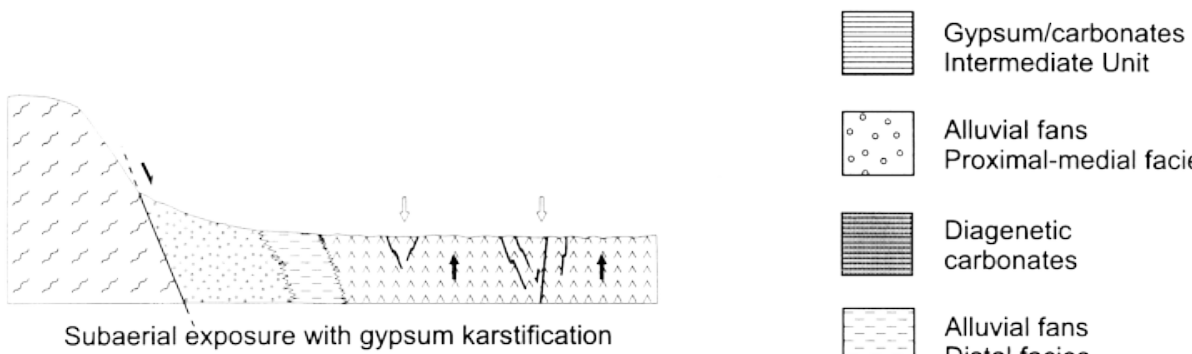

$\therefore \quad$ Alluvial fans

$\therefore \circ$ Proximal-medial facies

Diagenetic

carbonates

Subaerial exposure with gypsum karstification

Alluvial fans

Distal facies
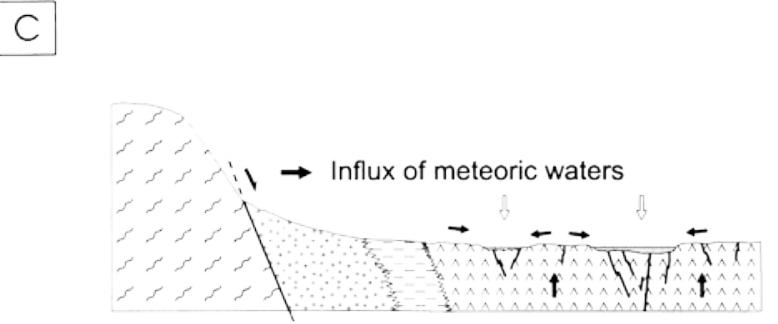

Sedimentation of laminated primary gypsum/magnesite-dolomite carbonates in the more active karstified subsidence areas
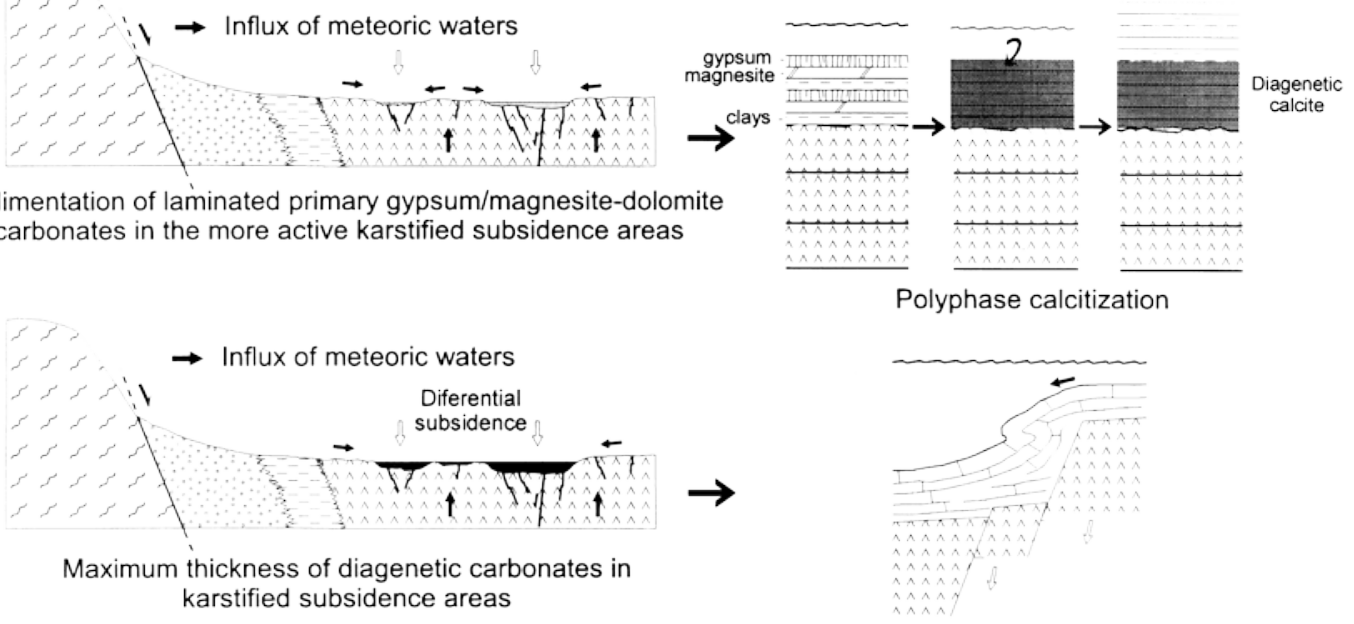
karstified subsidence areas
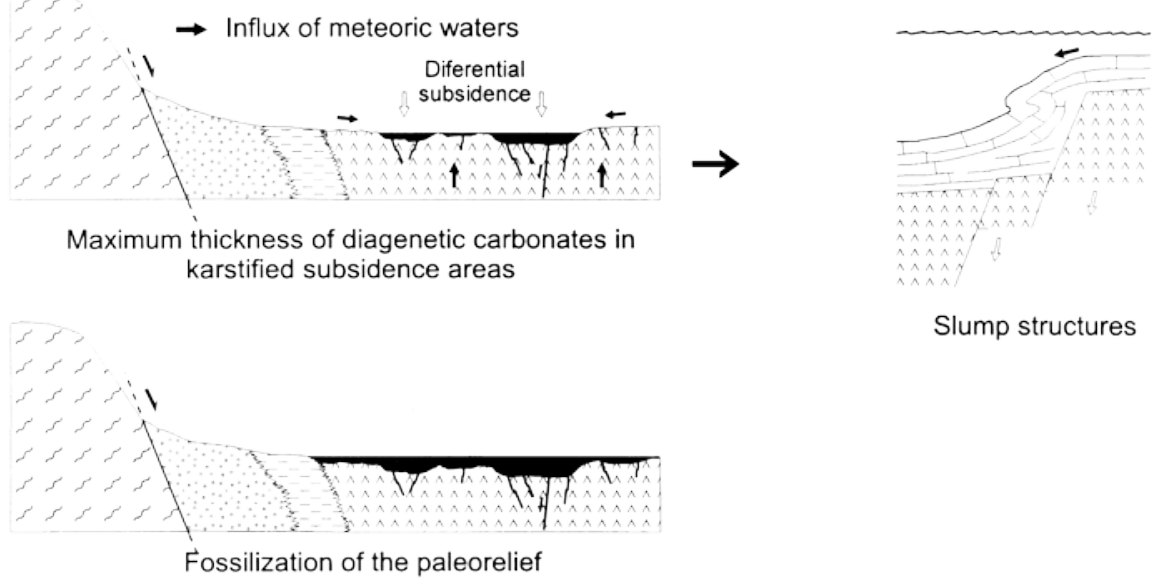

Slump structures

Moreover, Canaveras et al. (1998) showed similar mechanisms affecting exposed evaporite sequences during the recent exhumation of the basin and the emplacement of the recent fluvial drainage system.
The reaction of dolomite with Ca-enriched fluids, probably derived from gypsum dissolution, constitutes the most-common mechanism suggested for dedolomitization (Evamy, 1967; Folkman, 1969; Sánchez-Moral 
et al., 1993). The reaction products are calcium carbonate and magnesium sulphate, the latter being very soluble and rarely preserved. The dissolution of interbedded and intrasedimentary gypsum contributes to the process of dedolomitization by providing an abundant supply of calcium, which maintains a low $\mathrm{Mg} / \mathrm{Ca}$ ratio in the solution. Under these conditions, dolomite is unstable and dissolves with concurrent precipitation of calcite because of the common-ion effect, in order to maintain equilibrium where gypsum dissolution was the driving mechanism for dedolomitization and karstification processes. The chemical reaction of

dolomite dissolution has been proposed by numerous authors. This reaction is related directly to the formation of epsomite as follows:

$$
\underset{\text { Dolomite }}{\mathrm{CaMg}\left(\mathrm{CO}_{3}\right)_{2}}+\underset{\text { Gypsum }}{\mathrm{CaSO}_{4}(\mathrm{aq})--}+\underset{\text { Calcite }}{2 \mathrm{CaCO}_{3}}+\mathrm{Mg}^{2+}+\mathrm{SO}_{4}^{2-}
$$

Dedolomitization processes and the accompanying formation of epsomite $\left(\mathrm{MgSO}_{4} \cdot 7 \mathrm{H}_{2} \mathrm{O}\right)$ efflorescences as a by-product in the evaporite sequences of the Calatayud Basin have been supported by detailed petrographic and geochemical analysis (Sánchez-Moral et al., 1993).

On the other hand, as proposed by Canaveras et al. (1998), the calcitization of magnesite proceeds according to the following reactions:

$$
\begin{aligned}
& \underset{\text { Gypsum }}{\mathrm{CaSO}_{4}(\mathrm{aq})}+\underset{\text { Magnesite }}{\mathrm{MgCO}_{3}}--\underset{\text { Calcite }}{\mathrm{CaCO}_{3}}+\mathrm{Mg}^{2+}+\mathrm{SO}_{4}^{2-} \\
& \underset{\text { Glauberite }}{\mathrm{Na}_{2} \mathrm{Ca}\left(\mathrm{SO}_{4}\right)_{2}(\mathrm{aq})}+\underset{\text { magnesite }}{\mathrm{MgCO}_{3}}--\underset{\text { Calcite }}{\mathrm{CaCO}_{3}}+2 \mathrm{Na}^{+} \\
& +\mathrm{Mg}^{2+}+2 \mathrm{SO}_{4}^{2-}
\end{aligned}
$$

The dissolution of interbedded gypsum and/or glauberite drives the replacement of magnesite by calcite by providing Ca-enriched fluids, producing calcite and releasing dissolved magnesium and sulphate. The interaction of magnesite with Ca-enriched fluids derived from the dissolution of overlying or interbedded gypsum and/or glauberite beds is regarded as the driving force of this process. The by-products of the calcitization process are magnesium sulphate and/or sodium sulphate solutions leading to further precipitation of epsomite or mirabilite-thenardite efflorescences, respectively.

The carbonate replacement of sulphate involves at least two different mechanisms (Pierre and Rouchy, 1988): (a) bacterial sulphate reduction in organic-rich sediments, and (b) sulphate dissolution by bicarbonate-bearing waters. The former has been ruled out in view of stable isotope considerations, as well as the absence of both organic-rich sediments and native sulphur accumulations. In which case, the calcitization of gypsum or anhydrite would proceed according to the following reaction:

$\mathrm{CaSO}_{4}+2 \mathrm{HCO}^{-}$

Gypsum

$$
3^{--}+\underset{\text { Calcite }}{\mathrm{CaCO}_{3}}+\mathrm{CO}_{2}+\mathrm{H}_{2} \mathrm{O}+\mathrm{SO}_{4}
$$

the bicarbonate ions being mainly originated from $\mathrm{CO}_{2}$ dissolved in the water as a product of the oxidation of organic compounds of lacustrine or terrestrial origin.

\subsection{Palaeogeographic controls on the formation of the diagenetic carbonates}

We have interpreted the diagenetic carbonates recognized throughout the basin as a result of a complex multistep transformation process during the Middle Miocene (polyphase calcitization). According to the proposed model (Fig. 8), the concentration stages of the brine during the time interval of the Intermediate Unit, resulting in gypsum/magnesitedolomite deposits, were followed by dilution of lake water which caused the calcitization of the previous sediment, this process becoming progressively dominant through time. The repetitive superposition of the evaporite and carbonate deposits and their subsequent calcitization gave rise to the thick bodies of diagenetic laminated carbonates. These processes were intimately related to the evolution of the sedimentary fill in central parts of the basin and to its interplay with fault systems developed in the area (Hoyos et al., 1996; Sanz-Rubio et al., 1997). Several evolutionary stages could be distinguished (Fig. 8):

(1) Subaerial exposure of the evaporite deposits of the Lower Unit and development of a palaeokarstic surface as a result of relative drop of the water table (Fig. 8A and B). The exhumation of the evaporite deposits caused the transformation of anhydrite and/ or glauberite to secondary gypsum in the uppermost part of the Lower Unit.

(2) Deposition of laminated facies consisting of primary gypsum/magnesite-dolomite carbonates in 
the more rapidly subsiding and karstified gypsiferous areas which are controlled by NW-SE faults (Fig. 8C). Therefore, the deposition of the lower part of the Intermediate Unit was diachronous, resulting in significant variations in thickness.

The beginning of the deposition of the Intermediate Unit was marked by a change in the hydrochemical composition of the brines, with increased input of $\mathrm{HCO}_{3}^{-}$enriched meteoric waters and a drop in salinity of lake water. Stable isotope (carbon and oxygen) analysis of the diagenetic carbonates indicates an influence of meteoric-derived carbonate-rich groundwaters in their formation. The replacement resulted from early diagenetic processes occurring either at the contact of synsedimentary deposits with overlying freshwater or at very shallow burial depths when meteoric fluids percolated into the evaporitic units throughout a dense network of joints, thus favouring the infiltration and subsurface circulation of meteoric waters. Due to the differential loading caused by the deposition of the earliest sediments of the Intermediate Unit, the burial is not regular throughout the basin (Fig. 8D).

Increasing input of meteoric waters induced synsedimentary-early calcitization (polyphase calcitization) of the Intermediate Unit sediments in the subsiding areas (Fig. 8C). The meteoric fluids percolated into the evaporitic beds through a dense network of joints, thus favouring the subsurface circulation of meteoric waters and gypsum dissolution, which collectively gave rise to collapse features and the development of dolines. Deformation structures (slumps) and microfractures developed in the overlying diagenetic carbonates (Fig. 8D).

(3) Repeated episodes of calcitization gave rise to maximum thickness of diagenetic carbonates in the subsiding parts of the basin which correspond to the areas initially affected by the karstification (Fig. 8C and D). The final stage of calcitization, which was related to more abundant influx of meteoric water, affected the top of the Intermediate Unit, coeval to the fossilization of the paleorelief (Fig. 8E).

The appearance of diagenetic carbonates in the basin implies a threshold within a general trend to less saline waters observed from the Lower to the top of the Intermediate Unit. An important hydrochemical change occurred at the transition from the Lower Unit, which formed predominantly under hypersaline lacustrine conditions, to the Intermediate Unit, where less saline conditions are recorded by presence of primary gypsum interbedded with carbonates, mainly dolomite with subordinate magnesite. Moreover, the upward decrease of gypsum vs. carbonates and magnesite vs. dolomite throughout the Intermediate Unit provides evidence of a progressive dilution of the lake water, which finally resulted in sedimentation of palustrine deposits under possibly freshwater conditions. The overcoming of this threshold implies that changes in hydrochemistry were enough to activate processes resulting in the diagenetic replacement by calcite.

The uppermost levels of the Intermediate Unit, comprising thick sequences of brecciated carbonates, show widespread diagenetic fabrics formed at relatively shallow depths caused by the action of sulphate-poor surface-derived ground waters of meteoric origin. These carbonates are related to an intra-Vallesian paleokarstic surface and record a complex history of dissolution, collapse and infilling processes which were responsible for typical karst structures, such as caves, collapse breccia, speleothems.

A similar trend in the vertical evolution of contemporary terrestrial successions can be observed from basin to basin in the Iberian Peninsula. A significant lithological change between thick lacustrine evaporite successions and sequences dominated by alluvial, carbonate and gypsum deposits have been recognized in the Ebro and Madrid Miocene basins (Calvo et al., 1993). In the Calatayud Basin, the boundary between the Lower and Intermediate Units indicates a reversal of the saline precipitation. Thus, halite deposits in the lower part of the successions are covered by halite/ anhydrite deposits and these are in turn overlain by anhydrite-gypsum/magnesite materials. The final stages of the sedimentary fill of the basin are dominated by the deposition of $\mathrm{Mg}-\mathrm{Ca}$ and $\mathrm{Ca}$ carbonates sediments. A reversal of the precipitation sequence is induced by a dilution of the brine, which can be triggered by climatic or geologic causes (Fulda, 1924), that in our case could be explained by a generalized climate change towards more humid conditions. As indicated by the presence of a rich mammalian fauna, this change towards cooler and more humid climate occurred around 14 Ma during the Neogene Mammal Zone Mn 5 (Van der Meulen and Daams, 
1992; Krijgsman et al., 1994). In the same sense, the marine record clearly shows that major paleoceanographic and paleoclimatic changes occurred in the Middle Miocene (Flower and Kennett, 1993, among others).

\section{Conclusions}

The Calatayud Basin displays clear changes in lacustrine sedimentation, with evaporites of the Lower Unit being followed by more extensive evaporite-carbonate deposits of the Intermediate Unit. These units are separated by a sedimentary discontinuity that is marked either by a paleokarstic surface on gypsum deposits or, locally, by a drastic change in lithology upwards in the sections. The Intermediate Unit is in turn overlain by the Upper Unit, formed of terrigenous and lacustrine carbonates typical of deposition from fresh-water lakes.

Two types of diagenetic carbonates, laminated and brecciated, formed in the Calatayud Basin during the Miocene by calcitization of evaporite (gypsum, anhydrite) and/or magnesium carbonate (dolomite, magnesite). They are especially well exposed in the central part of the basin, particularly in the Intermediate Unit where they commonly constitute large bodies bounded by the aforementioned sedimentary discontinuities.

The diagenetic carbonates consist of low magnesian calcite and were generated during early diagenetic stages. Stable isotopes (carbon and oxygen) analysis of the diagenetic carbonates indicates an influence by meteoric-derived carbonate rich-groundwater for the formation of these materials. The calcite replacement, having taken place during the middle Miocene, resulted from early diagenetic processes occurring either at the contact of synsedimentary deposits with overlying freshwater or under very shallow burial depths. At this time meteoric fluids percolated into the evaporitic beds through a dense network of joints that favoured the infiltration and subsurficial circulation of meteoric waters. The proposed model for calcitization of the Miocene evaporite deposits is supported by petrographic and geochemical evidences provided by recent calcitization products recognized in the basin.

The formation of the diagenetic carbonates was contemporary with an increased influx of meteoric waters, ultimately related to an intra-Miocene climate change towards cooler and more humid conditions. A similar trend in the vertical evolution of terrestrial successions of the same time interval has been recognized in other basins of the Iberian Peninsula.

\section{Acknowledgements}

This work has been done in memory of Dr Manuel Hoyos Gómez, initiator of this research and kindly friend for all the authors that participated in this manuscript. This work was supported by Spanish D.G.I.C.Y.T. projects PB95-0112, PB97-0244 and PB98-0503. Catherine Pierre (Universite Pierre et Marie Curie, Paris) is acknowledged for the stable isotope study and helpful suggestions to improve the initial version of the manuscript. Mineralogical analyses were conducted with the assistance of $\mathrm{R}$. González (MNCN-CSIC). Our thanks to H.M. Pedley, M. Talbot and C. Taberner for their constructive reviews and comments on the submitted manuscript. The authors are grateful to E. Nicol's and M. Russell for useful suggestions in the final English version.

\section{References}

Anadón, P., Utrilla, R., 1993. Sedimentology and isotope geochemistry of lacustrine carbonates of the Oligocene Campins Basin, north-east Spain. Sedimentology 40, 699-720.

Anadó, P., Rosell, L., Talbot, M.R., 1992. Carbonate replacement of lacustrine gypsum deposits in two Neogene continental basins, eastern Spain. Sediment. Geol. 78, 201-216.

Bell, C.M., 1989. Saline lake carbonates within an Upper JurassicLower Cretaceous continental red bed sequence in the Atacama region of northern Chile. Sedimentology 36, 651-663.

Bellanca, A., Calderone, S., Neri, R., 1986. Isotope geochemistry, petrology and depositional environments of the diatomite-dominated Tripoli Formation (Lower Messinian), Sicily. Sedimentology 33, 729-743.

Budai, J.M., Lohmann, K.C., Owen, R.M., 1984. Burial dedolomite in the Mississippian Madison Limestone, Wyoming and Utah thrust belt. J. Sediment. Petrol. 54, 276-288.

Calvo, J.P., Daams, R., Morales, J., L'́pez-Mart'Inez, N., Agust'I, J., Anadò, P., Armenteros, I., Cabrera, L., Civis, J., Corrochano, A., D'laz-Molina, M., Elizaga, E., Hoyos, M., MartIn-Suarez, E., Mart'Inez, J., Moissenet, E., Munoz, A., P'erez-Garc'la, A., P'erezGonzdlez, A., Portero, J.M., Robles, F., Santisteban, C., Torres, T., Van der Meulen, A.J., Vera, J.A., Mein, P., 1993. Up-to-date Spanish continental Neogene synthesis and paleoclimatic interpretation. Rev. Soc. Geol. Espaна 6 (3-4), 29-40. 
Canaveras, J.C., Sánchez-Moral, S., Calvo, J.P., Hoyos, M., Ordó неz, S., 1996. Dedolomites associated with karstification, an example of early dedolomitization in lacustrine sequences from the Tertiary of the Madrid Basin, Central Spain. Carbonates and Evaporites 11, 85-103.

Canaveras, J.C., Sảnchez-Moral, S., Sanz-Rubio, E., Hoyos, M., 1998. Meteoric calcitization of magnesite in Miocene lacustrine deposits (Calatayud Basin, NE Spain). Sediment. Geol. 119, 183-194.

Decima, A., McKenzie, J.A., Schreiber, B.C., 1988. The origin of evaporative limestones: an example for the Messinian of Sicily. J. Sediment. Petrol. 58, 256-272.

Evamy, B.D., 1967. Dedolomitization and the development of rhomboedral pores in limestones. J. Sediment. Petrol. 37, 1204-1215.

Flower, B.P., Kennett, J.P., 1993. Middle Miocene ocean-climate transition: high-resolution oxygen and carbon isotopic records from Deep Sea Drilling Project site 588 ${ }^{\mathrm{a}}$, Southwest Pacific. Paleoceanography 8, 811-843.

Folkman, Y., 1969. Diagenetic dedolomitization in the AlbianCenomanian Yagur dolomite on Mount Carmel (northern Israel). J. Sediment. Petrol. 39, 380-385.

Friedman, I., O'Neil, J.R., 1977. Compilation of stable isotope fractionation factors of geochemical interest. In: Fleischer, M. (Ed.), Data of Geochemistry, 6th ed. US Geol. Surv., Prof. Paper 440-KK, pp. 1-12.

Fulda, E., 1924. Studie u ber die Entstehung der Kalisalzlagersta tten des deutschen Zechsteins. Z. Dtsch. Geol. Ges. 76 (1-4), 7-30.

Goldsmith, J.R., Graf, D.L., 1958. Relation between lattice constants and composition of the Ca-Mg carbonates. Am. Miner. 43, 84-101.

Hoyos, M., Lípez-Mart'Inez, N., 1985. Iberic depression. In: Steininger, F.F., Senes, J., Kleeman, K., Ra gl, F. (Eds.), Neogene of the Mediterranean Tethys and Paratethys: Stratigraphic Correlation Tables and Sediment Distribution Maps. Int. Geol. Correl. Program, Project 25, Institute of Paleontology, University of Vienna, pp. 19-20.

Hoyos, M., Doblas, M., Sánchez-Moral, S., Canaveras, J.C., Ord'o неz, S., Sesé, C., Sanz-Rubio, E., Mahecha, V., 1996. Hydration diapirism: a climate-related initiation of evaporite mounds in two continental neogene basins of Central Spain. In: Blundell, G.I., Davidson, I. (Eds.), Salt Tectonics. Geol. Soc., Spec. Publ. 100, pp. 49-63.

Hoyos, M., Sanz-Rubio, E., Sánchez-Moral, S., Canaveras, J.C., Calvo, J.P., 1998. Updating of the stratigraphy and evaluation of the climatic and/or tectonic influence in the sedimentary ruptures of the Calatayud Basin. In: Canaveras, J.C., Garc'la del Cura, M.A., Soria, J. (Eds.), Sedimentology at the Dawn of the Third Millennium. 15th International Sedimentological Congress, Alicante, Spain, April, p. 435.

International Atomic Energy Agency, 1992. Statistical treatment of data of environmental isotopes in precipitation. Technical Reports Series, Vienna, 331 pp.

Jacobs, L., Swennen, R., Van Orsmael, J., Notebaert, L., Viaene, W., 1982. Occurrences of pseudomorphs after evaporitic minerals in the Dinantian carbonate rocks of the eastern part of Belgium. Bull. Soc. Belge Géol. 91, 105-123.
Kastner, M., 1982. When does dolomitization occur and what controls it? 11th Int. Cong. Sed. (Abstract). Hamilton, Ontario, Canada, p. 124.

Kirkland, D.W., Evans, R., 1976. Origin of Limestone Buttes, Gypsum Plain, Culherson County, Texas. Am. Assoc. Petrol. Geol. Bull. 60, 2005-2018.

Kralik, M., Aharon, P., Schroll, E., Zachmann, D., 1989. Carbon and oxygen isotope systematics of magnesites: a review. In: Mu ller, P. (Ed.), Magnesite, Geology, Mineralogy, Geochemistry, Formation of Mg-carbonates. Monograph Series on Mineral Deposits 28, pp. 197-223.

Krijgsman, W., Langereis, C.G., Daams, R., Van der Meulen, A.J., 1994. Magnetostratigraphic dating of the middle Miocene climate change in the continental deposits of the Aragonian type area in the Calatayud-Teruel basin (Central Spain). Earth Planet. Sci. Lett. 128, 513-526.

Last, W.M., 1990. Lacustrine dolomite - an overview of modern, Holocene and Pleistocene occurrences. Earth-Sci. Rev. 27, 221-263.

McKenzie, J.A., Hsu, K.J., Schneider, J.F., 1980. Movement to subsurface waters under the sabkha, Abu Dhabi, U.A.E., and its relationship to evaporative dolomite genesis. In: Zenger, D.H., Dunham, J.B., Ethington, R.L. (Eds.), Concepts and Models of Dolomitization. Soc. Econ. Paleontol. Mineral., Spec. Publ. 28, pp. 11-30.

OrtI', F., Rosell, L., 1994. Origen glauber'Itico del cuerpo central de los yesos de Calatayud. Com. II Congr. del Grupo Espanol del Terciario (Jaca, Huesca, Spain), pp. 255-258.

Pierre, C., Rouchy, J.M., 1988. Carbonate replacements after sulphate evaporites in the Middle Miocene of Egypt. J. Sediment. Petrol. 58, 446-456.

Rebelle, M., 1987. Phénoménes de remplacement sulfate-carbonate dans certains facies carbonatés du bassin évaporitique du Zechstein: pérographie et géochimie isotopique. Eight Eur. Reg. Meeting of Sedimentology. I.A.S., Tunis.

Rossi, C., Canaveras, J.C., 1999. Pseudospherulitic fibrous calcite in paleo-groundwater, unconformity-related diagenetic carbonates (Paleocene of the Ager basin and Miocene of the Madrid basin, Spain). J. Sedim. Res. 69, 224-238.

Rouchy, J.M., Bernet-Rollande, M.C., Maurin, A., 1994. Descriptive petrography of evaporites: applications in the field, subsurface and the laboratory. In: Evaporite Sequences in Petroleum Exploration. Ed. Technip, Paris, pp. 70-123.

Rouchy, J.M., Taberner, C., Blanc-Valleron, M.M., Sprovieri, R., Russell, M., Pierre, C., Di Stefano, E., Pueyo, J.J., Caruso, A., Dinares, J., Gomis-Coll, E., Cespuglio, G., Wolff, G., Ditchfield, P., Santisteban, C., Pestrea, S., Combourieu-Nebout, N., Santisteban, S., Grimalt, J.O., 1998. Sedimentary and diagenetic markers of the restriction in a marine basin: the Lorca basin (SE Spain) during the Messinian. Sediment. Geol. 121, 23-55.

Sánchez-Moral, S., Hoyos, M., Ord'̌nez, S., Garcla del Cura, M.A., Canaveras, J.C., 1993. Génesis de epsomita infiltracional por dedolomitización en ambiente sulfatado árido: eflorescencias en la Unidad Inferior evaporltica de la Cuenca de Calatayud. V Congreso de Geoqu'mica de Espana, Soria, pp. 24-29.

Sanz-Rubio, E., 1999. Análisis de los sistemas deposicionales carbonáticos y evaporíticos del Neógeno de la Cuenca de 
Calatayud (provincia de Zaragoza). Unpublished $\mathrm{PhD}$ thesis, Universidad Complutense de Madrid, 579 pp.

Sanz-Rubio, E., Hoyos, M., Calvo, J.P., Sánchez-Moral, S., Canaveras, J.C., Sesè C., 1997. Paleokarstificaciones y evolución de los sistemas deposicionales miocenos de la Cuenca de Calatayud. In: Alcalá L., Alonso Zarza, M.A. (Eds.), Itinerarios geológicos en el Terciario del centro y este de la PenInsula Ibérica. Dept. de Petrolog'́a y GeoquIImica-UCM y Museo Nac. C. Nat.-CSIC, Madrid, pp. 109-134.

Sanz-Rubio, E., Hoyos, M., Sánchez-Moral, S., Canaveras, J.C., Rouchy, J.M., 1998. Calcitization of Mg-carbonates and Casulphate deposits in a continental tertiary basin, Calatayud Basin (NE Spain). In: Canaveras, J.C., Garc'Ia del Cura, M.A., Soria, J. (Eds.), Sedimentology at the Dawn of the Third Millennium. 15th International Sedimentological Congress, Alicante, Spain, April, p. 697.

Servant-Vildary, S., Rouchy, J.M., Pierre, C., Foucault, A., 1990. Marine and continental water contributions to a hypersaline basin using diatom ecology, sedimentology and stable isotopes: an example in the Late Miocene of the Mediterranean (Hellin basin, Southern Spain). Palaeogeogr., Palaeoclimatol., Palaeoecol. 79, 189-204.

Sharma, T., Clayton, R.N., 1965. Measurements of ${ }^{18} \mathrm{O} /{ }^{16} \mathrm{O}$ ratios of total oxygen and carbonates. Geochim. Cosmochim. Acta 29, 1347-1353.

Tucker, M.E., 1978. Gypsum crusts (gypcrete) and patterned ground from northern Iraq. Z. Geomorph. N.F. 22, 89-100.

Van der Meulen, A.M., Daams, R., 1992. Evolution of early-middle Miocene rodent faunas in relation to long-term paleoenvironmental changes. Palaeogeogr., Palaeoclimatol., Palaeoecol. 93, 227-253.

Wigley, T.M.L., 1973. Chemical evolution of the system calcitegypsum water. Can. J. Earth Sci. 10, 306-315.

Youssef, E.A.A., 1989. Geology and genesis of sulphur deposits at Ras Gemsa area, Red Sea Coast, Egypt. Geology 17, 797801. 